\section{Food environment of fruits and vegetables in the territory of the Health Academy Program}

\author{
Ambiente alimentar de frutas e hortaliças no \\ território do Programa da Academia da Saúde
}

\author{
Ambiente alimentar de frutas y verduras en el \\ territorio del Programa Academia de la Salud
}

\begin{abstract}
This study provides a spatial analysis of distribution and access to commercial fruit and vegetable establishments within the territory of a representative sample of public fitness facilities known as the Health Academy Program (HAP) in Belo Horizonte, Minas Gerais State, Brazil. The study evaluated commercial food establishments within a buffer area based on a radius of 1,600 meters around each of 18 randomly selected fitness facilities. Quality of access to fruits and vegetables was assessed by the Healthy Food Store Index (HFSI), consisting of the variables availability, variety, and advertising of fruits, vegetables and ultra-processed foods. The analy sis was based on calculation of the Kernel intensity estimator, nearest neighbor method, and Ripley K-function. Of the 336 food establishments, $61.3 \%$ were green grocers and open-air markets, with a median HFSI of 11 (5 to 16). In only 17\% of the territories, the majority of the "hot area" establishments displayed better access to healthy foods, and only three areas showed a clustering pattern. The study showed limited access to commercial establishments supplying healthy fruits and vegetables within the territory of the public fitness program.
\end{abstract}

Commerce; Food; Spatial Analysis;

Urban Health
Bruna Vieira de Lima Costa 1 Cláudia Di Lorenzo Oliveira 2 Aline Cristine Souza Lopes 1

\section{Resumo}

Analisar espacialmente a distribuição e o acesso a estabelecimentos comerciais de frutas e hortaliças no território de uma amostra representativa de polos do Programa Academia da Saúde (PAS) de Belo Horizonte, Minas Gerais, Brasil. Avaliaram-se estabelecimentos contidos dentro de buffers com raios de 1.600 metros a partir de 18 polos amostrados aleatoriamente. A qualidade do acesso às frutas e hortaliças foi avaliada pelo Índice de Acesso a Alimentos em Estabelecimentos (HFSI), composto por variáveis de disponibilidade, variedade e propaganda de frutas e hortaliças e alimentos ultraprocessados. A análise constou do cálculo do estimador de intensidade kernel, método do vizinho mais próximo e função K de Ripley. Dos 336 estabelecimentos, 61,3\% eram sacolões e feiras-livres, com mediana de HFSI 11 (5 a 16). Em apenas 17\% dos territórios analisados, a maioria dos estabelecimentos da área quente apresentava melhor acesso a alimentos saudáveis, sendo que apenas três áreas apresentaram padrão de aglomeração. Verificou-se acesso limitado a estabelecimentos comerciais que ofertam frutas e hortaliças com qualidade no território do PAS.

Comércio; Alimentos; Análise Espacial;

Saúde Urbana 


\section{Introduction}

Food environment is defined as the territory in which people live and work and that impacts their nutritional health 1 . The territory consists of areas with spaces for interpersonal and person-environment interrelations 2 . Territory is not merely a physical place, but a locus for health promotion, where subjects act collectively to improve their living and health conditions 3 .

Health promotion thus features intersectoral and community participation, its principal locus is Primary Health Care, which is the focus of the current study and an important scenario for promoting healthy eating. Adequate and healthy eating requires strengthening the intersectoral basis of equipment and policies within the territory, considering the food environment with a view towards universal access, as recommended in Brazil by the National Policies on Food and Nutrition and Food and Nutritional Security 4 .

Studies have used different methods to measure the food environment. The macro level includes variables like number, type, location, and distance to food establishments, while the micro level encompasses quality, price, promotion, availability, and variety of the food products 5 .

The type of establishment and food product characteristics such as availability, quality, and price have a particularly strong influence on individual food purchases $6,7,8$. Supermarkets, green grocery stores, and open-air markets tend to supply more healthy foods than mixed markets and convenience stores, thereby directly impacting consumers' choices 9 .

A suggestion for mapping the food environment ${ }^{1}$ has been to monitor the offer of healthy versus unhealthy foods in the retail food sector, including type, availability, and access to pointsof-sale for foods. Such monitoring should identify opportunities for healthy eating, based on the existence of (and proximity to) stores with fresh and healthy food products, such as those supplying fruits and vegetables 7,10 .

The current study aimed to analyze spatial distribution and access to commercial fruit and vegetable establishments within the territory of a public fitness equipment program called the "Health Academy Program" or HAP in Belo Horizonte, Minas Gerais State, Brazil. This program was chosen to define the territory because Primary Care is a key component of the Brazilian Unified National Health System, which recommends intersectoral collaboration and community participation in dealing with the social determinants of health. The program's action should thus involve the development of indi- vidual skills, reinforcement of collective interventions, and the creation of favorable environments for healthy eating 11 . Information on the HAP territory would thus allow mapping the need for implementing and reinforcing public food and nutrition policies that favor a healthy food environment, such as public policies aiming the improvement of food offer. Such information would also help strengthen activities in food and nutritional education combined with this public fitness program, aimed at promoting healthy eating through information on access to (and quality of) fresh foods like fruits and vegetables 12 .

\section{Methods}

This was an exploratory ecological study on the spatial distribution of establishments that sell fruits and vegetables in the HAP territory in Belo Horizonte, capital of Minas Gerais State, with a population of 2,375,151 in 2010 (Brazilian Institute of Geography and Statistics. Censo Demográfico 2010. http:/ / censo2010.ibge.gov.br, accessed on $10 / \mathrm{Feb} / 2014)$. The city is divided into nine administrative districts.

The study selected a representative sample of the HAP units, stratified by the city's administrative districts. A total of 18 units were selected, or two per administrative district (Figure 1). The sampling process considered 42 eligible public fitness units out of the 50 installed in the city in 2012. Six units located in areas with low health vulnerability were excluded due to the small number of units with this characteristics and the fact that there was no matching unit in the same district to include in the sample. Two other units were excluded due to intense health eating promotion activities previously to the current survey.

The study's database included establishments that sold fruits and vegetables, obtained from the registry of the Municipal Joint Taxation Secretariat (SMAA), with two databases, plus open-air produce markets and food establishments that were found spontaneously but were not registered in the above-mentioned databases. The first database was obtained in December 2012 and includes wholesale and retail fruit and vegetable businesses. The second includes retail merchandise establishments in general and was obtained in April 2013, based on the food subclass in the National Classification of Economic Activities. Both databases were previously georeferenced. Open-air produce markets were located from the website of the Belo Horizonte Municipal Government (http://www.pbh.gov.br).

Starting from the geographic position of the HAP units, we constructed "buffers" with a radi- 


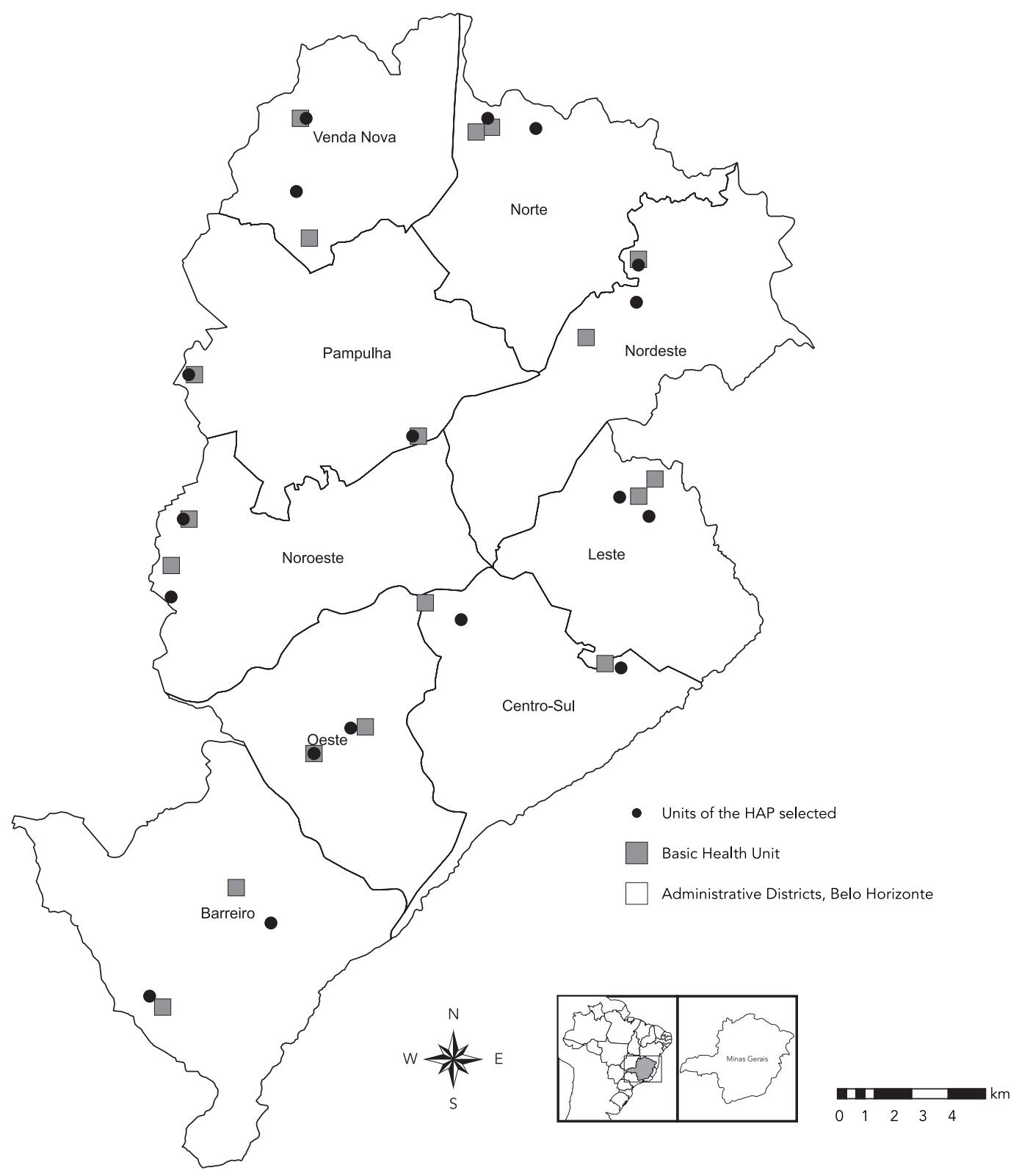

us of 1,600 meters (or 1 mile). All establishments selling fruits and vegetables and located within each respective radius were considered potential study participants.

The analysis excluded the areas of influence of units that contained fewer than 10 commercial establishments, due to their instability.
The study questionnaire was based on the Auditing Tool for Markets/Supermarkets/Grocery Stores from the ESAO study (São Paulo Survey on the Obesogenic Environment), prepared and tested by Duran et al. ${ }^{9}$, with all the variables collected according to the questionnaire's manual. 
Data were collected at the macro and micro levels. Macro data refer to the location and type of commercial establishments. Micro level data included access to the establishments and the time since they opened for business.

Access was measured by the Healthy Food Store Index (HFSI) currently selling food for home consumption. The index varies from 1 to 16 and consists of the availability, variety, and advertising of healthy items (fruits and vegetables) versus ultra-processed items (sweetened beverages, corn chips, and cream-filled chocolate cookies). Our analysis only included establishments that agreed to participate in the study and that authorized the data collection.

The collected data were used to construct point maps based on the buffers, in order to visualize the types of establishments and the respective HFSI values in each HAP territory. This article presents the representative maps and their distinct characteristics.

To analyze the spatial distribution of commercial fruit and vegetable establishments in the target territories, we used the Kernel estimator, aimed at identifying the existence of spatial clustering in the units. This estimator is an interpolator, allowing estimation of the event's intensity in the entire area. A two-dimensional function of the events is adjusted for this purpose, producing a surface whose value is proportional to the intensity of samples per area unit 13 . For this method, we adopted a cell size of 6.4 , which was obtained by dividing the radius of the unit's area of influence (1,600 meters) by 250 . Meanwhile, the bandwidth or radius of influence, which defines the neighborhood of the point to be interpolated and controls the smoothing of the resulting surface, was set at 1,600 meters, corresponding to the same value used for the radius.

To analyze the distribution pattern of the commercial establishments in the HAP territory and thus determine the establishments that displayed a random versus non-random pattern, we used the nearest neighbor method and Ripley's K-univariate function. The nearest neighbor method estimates the distribution of the cumulative distribution function based on the distance between events in a target region and can be used as a formal method to statistically compare the distribution of observed versus expected events, under the hypothesis of complete spatial randomness. Ripley's K-function represents the spatial dependency of the process and is derived from the spatial correlation structure. Spatial dependency is measured by estimating the relationship between pairs of events in space, corresponding to an approximation of the calculation of covariance between the random variables 13 .
Thus, the radius (h) used to calculate $\mathrm{k}(\mathrm{h}$ ) was 160 meters, and the analyses were performed up to a distance of 1,600 meters, corresponding to the HAP territory. Confidence envelopes were created using 999 random simulations.

Directional distribution ellipse was used to demonstrate the spatial trend of the commercial establishments. This ellipse is a measure of variation or dispersal, with a central point as the base, taking into consideration the magnitude or weight of the locations ${ }^{14}$.

Data were tabulated in Access 2010 (Microsoft Corp.) and georeferenced and analyzed with Arcview version 10.1 (Environmental Systems Research Institute Inc., http://www.esri.com/ software/arcview/).

The study was approved by the Ethics Research Committee of the Federal University in Minas Gerais and the Belo Horizonte Municipal Health Secretariat. The data were collected after receiving informed consent from the persons in charge of the commercial establishments.

\section{Results}

All 318 establishments belonging to the first database and the 13 open-air markets were eligible to participate in the study. As for the second database, of the total of 880 establishments, 385 were excluded because they did not sell fruits and vegetables (as verified by telephone contact) and 72 because they appeared twice in the database. Besides these commercial establishments, we added those found spontaneously in the HAP territory and not registered at (or georeferenced by) the municipal government.

A total of 754 establishments were visited, registered in the database and on the website of the Belo Horizonte Municipal Government. Of this total, $46.3 \%$ ( $\mathrm{n}=349$ ) did not exist, one was not an open-air market, and 172 were establishments (23\%) that did not sell fruits and vegetables. Of the total 233 eligible establishments, $20,6 \%$ ( $n=$ 48) refused to allow the data collection. In addition to this preliminary survey, we spontaneously found another 127 establishments (not listed in the municipal registry), of which $11 \%(n=14)$ refused to participate in the study. We thus collected data from 298 establishments, of which $173(60.5 \%)$ belonged to the database of the Belo Horizonte Municipal Government. We finally worked with a total de 336 establishments, since 38 belonged to territories of two different HAP units and had thus been allocated in both areas.

The majority of the establishments we visited were green grocery stores and open-air markets (61.3\%), followed by grocery stores and large 
chain supermarkets $(20.5 \%)$, and local markets (17.6\%). Median time since opening for business was 10 years, varying from 1 month to 52 years.

As for access, median HFSI was 11, varying from 5 to 16. In two HAP territories (Norte 1 and Norte 2), there were no establishments in the last tertile of HFSI, corresponding to the best access to healthy foods. Of the 18 study areas, seven (39\%) showed median HFSI in the first tertile $\leq 10$ ), for establishments with the best and worst access to healthy foods, respectively (Table 1).

Commercial establishments with better access to healthy foods and located in the region with the highest density of establishments ("hot area”), identified by Kernel estimator analysis, were only the majority in $17 \%(n=3)$ of the units (HAP: Oeste 1, Barreiro 2, Centro-Sul 1) (Figure 2). As shown in Figure 3, nearly half of the units $(44 \%, \mathrm{n}=8)$ mostly had establishments with worse HFSI (HAP: Centro-Sul 2, Leste 1 and 2, Norte 1, Nordeste 2, Oeste 2, Pampulha 2, and Barreiro 1). Two areas (HAP: Pampulha 2 and Norte 1) had zero establishments with satisfactory HFSI (Figure 3).
Of the 17 HAP territories, three units (HAP: Centro-Sul 1, Leste 1 and 2) showed clustering in the spatial distribution of establishments (Table 1 and Figure 4).

Only six HAP units (Leste 2, Barreiro 1, Centro-Sul 1, Leste 1, Nordeste 1, and Venda Nova 1) were located in the "hot area", i.e., they contained a higher concentration of fruit and vegetable establishments around them, based on kernel density analysis. As for the unit's location in relation to the ellipse of the establishments' directional distribution, 11 units (Centro-Sul 1, Leste 1 and 2 , Nordeste 1 and 2, Noroeste 1, Norte 1, Oeste 1 and 2, Venda Nova 1 and 2) were inside the ellipse, showing approximation to the establishments' directional trend (Figures 2 and 4).

Only three territories (HAP: Leste 1, Oeste 1, Venda Nova 1) contained establishments that were spatially distributed throughout the territory (Figure 2). Nine areas (HAP: Barreiro 1, Leste 1 and 2, Noroeste 1 and 2, Norte 1 and 2, Pampulha 1 , Venda Nova 2) were cut across by the city limits, and another nine (HAP: Barreiro 1 and 2, Centro-Sul 2, Leste 2, Noroeste 1 and 2, Norte 1,

Table 1

Description of commercial fruit and vegetable establishments in the territories of Health Academy Program (HAP). Belo Horizonte, Minas Gerais State, Brazil, 2013.

\begin{tabular}{|c|c|c|c|c|c|c|c|}
\hline \multirow[t]{2}{*}{ Region } & \multirow[t]{2}{*}{ HAP } & \multirow{2}{*}{$\begin{array}{l}\text { Establishments } \\
\text { (n) }\end{array}$} & \multicolumn{3}{|c|}{ Access } & \multirow{2}{*}{$\begin{array}{c}\text { Spatial } \\
\text { distribution * }\end{array}$} & \multirow[t]{2}{*}{$p$-value } \\
\hline & & & Median & Minimum & Maximum & & \\
\hline \multirow[t]{2}{*}{ Barreiro } & 1 & 10 & 10 & 5 & 15 & Randomness & $<0.001$ \\
\hline & 2 & 10 & 13 & 6 & 15 & Randomness & 0.01 \\
\hline \multirow[t]{2}{*}{ Centro-Sul } & 1 & 48 & 11 & 6 & 16 & Clustering & 0.006 \\
\hline & 2 & 12 & 11 & 5 & 14 & Randomness & $<0.001$ \\
\hline \multirow[t]{2}{*}{ Leste } & 1 & 33 & 11 & 6 & 16 & Clustering & 0.008 \\
\hline & 2 & 31 & 11 & 6 & 16 & Clustering & 0.01 \\
\hline \multirow[t]{2}{*}{ Nordeste } & 1 & 17 & 9 & 6 & 15 & Randomness & 0.12 \\
\hline & 2 & 16 & 9 & 6 & 14 & Randomness & 0.49 \\
\hline \multirow[t]{2}{*}{ Noroeste } & 1 & 18 & 11 & 6 & 15 & Randomness & 0.04 \\
\hline & 2 & 10 & 11.5 & 6 & 14 & Randomness & 0.03 \\
\hline \multirow[t]{2}{*}{ Norte } & 1 & 11 & 8 & 5 & 13 & Randomness & 0.33 \\
\hline & 2 & 09 & 6 & 5 & 13 & $\star \star$ & $\star \star$ \\
\hline \multirow[t]{2}{*}{ Oeste } & 1 & 17 & 13 & 7 & 15 & Randomness & 0.06 \\
\hline & 2 & 22 & 10 & 5 & 14 & Randomness & 0.65 \\
\hline \multirow[t]{2}{*}{ Pampulha } & 1 & 10 & 12 & 6 & 15 & Randomness & 0.005 \\
\hline & 2 & 15 & 10 & 6 & 14 & Randomness & 0.57 \\
\hline \multirow[t]{2}{*}{ Venda Nova } & 1 & 31 & 12 & 5 & 16 & Randomness & 0.19 \\
\hline & 2 & 16 & 11 & 6 & 16 & Randomness & 0.67 \\
\hline Total & - & 336 & - & - & - & - & \\
\hline
\end{tabular}

* Nearest neighbor method and K-Ripley function;

** Area of influence excluded from the spatial analysis. 
Spatial distribution of commercial establishments selling fruits and vegetables in the territory of the Health Academy Program (HAP)-Oeste 1. Belo Horizonte, Minas Gerais State, Brazil, 2013.

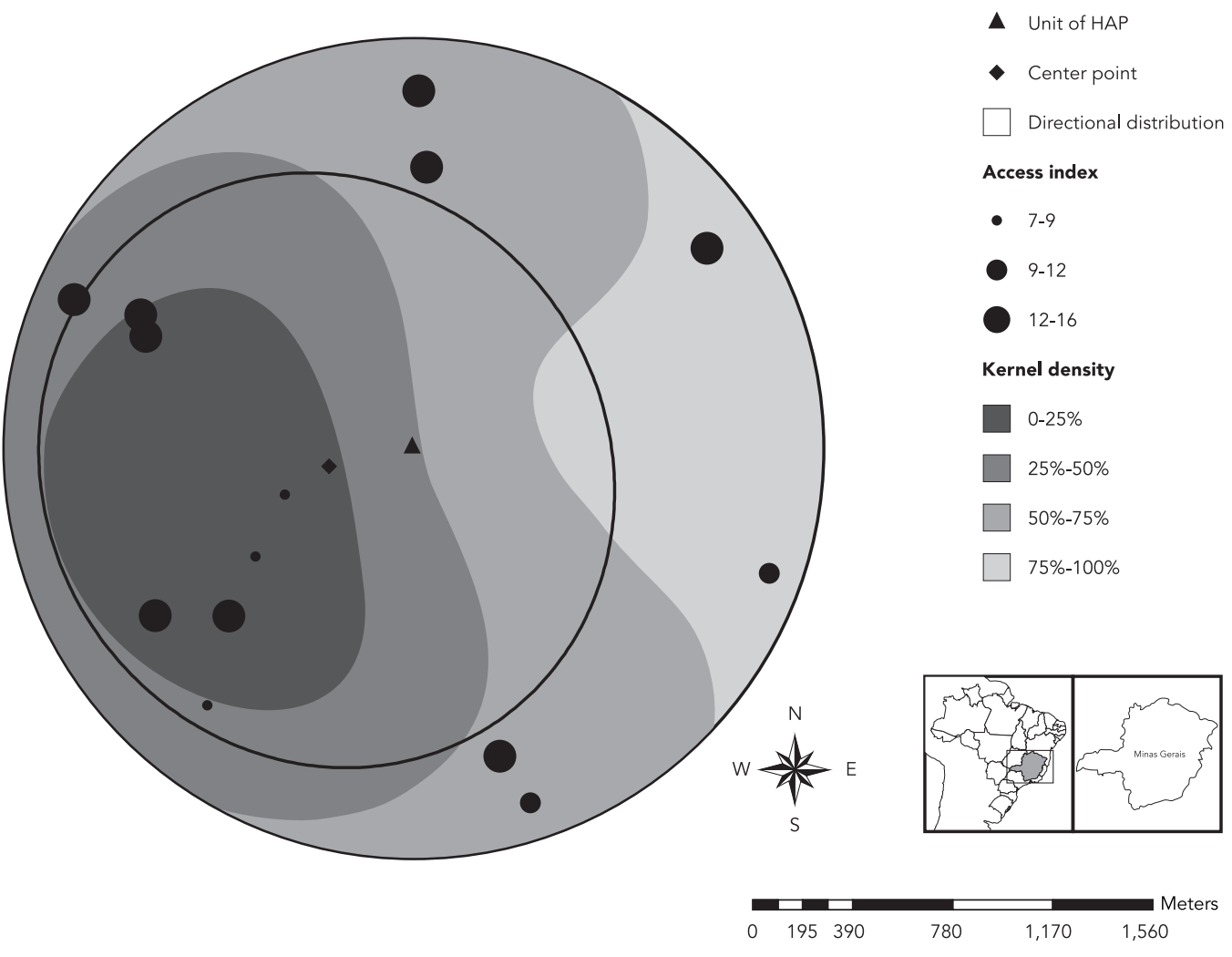

Pampulha 1 and 2) had large uninhabited spaces such as wooded parks and a university campus (Figure 3).

\section{Discussion}

The majority of the establishments contained in the HAP territories were classified as green grocery stores and open-air markets, but only two areas had establishments featuring better access to healthy foods. The HAP units were generally not located in regions with greater density of commercial establishments, and only one-sixth of the hot areas had establishments with better access to fruits and vegetables, i.e., with greater availability and variety of these foods rather than ultra-processed products.

Green grocery stores, open-air markets, and supermarkets, were the establishments most frequently found in the HAP territories. These establishments show greater availability, variety, and quality of produce supplied at lower cost, thus favoring access to fruits and vegetables $9,12,15,16,17,18,19$.

Studies show that ease of access to fruit and vegetable establishments and greater availability of healthy foods are associated in turn with greater household availability 20 and increased consumption of such foods 6,7,21,22. A study of data from the U.S. Food Stamp Program showed that easy access was associated with the consumption of one or more portions of fruits per day 6 . A study of African-American women in Detroit showed that increased consumption of fruits and vegetables was associated with food shopping in green grocery stores and supermarkets 7 . An ecological study of adults in São Paulo, Brazil, found that areas with greater concentration of green grocery stores and open-air markets showed higher rates of consumption of these healthy foods 23 . 
Spatial distribution of commercial establishments selling fruits and vegetables in the territory of the Health Academy Program (HAP)-Pampulha 2. Belo Horizonte, Minas Gerais State, Brazil, 2013.

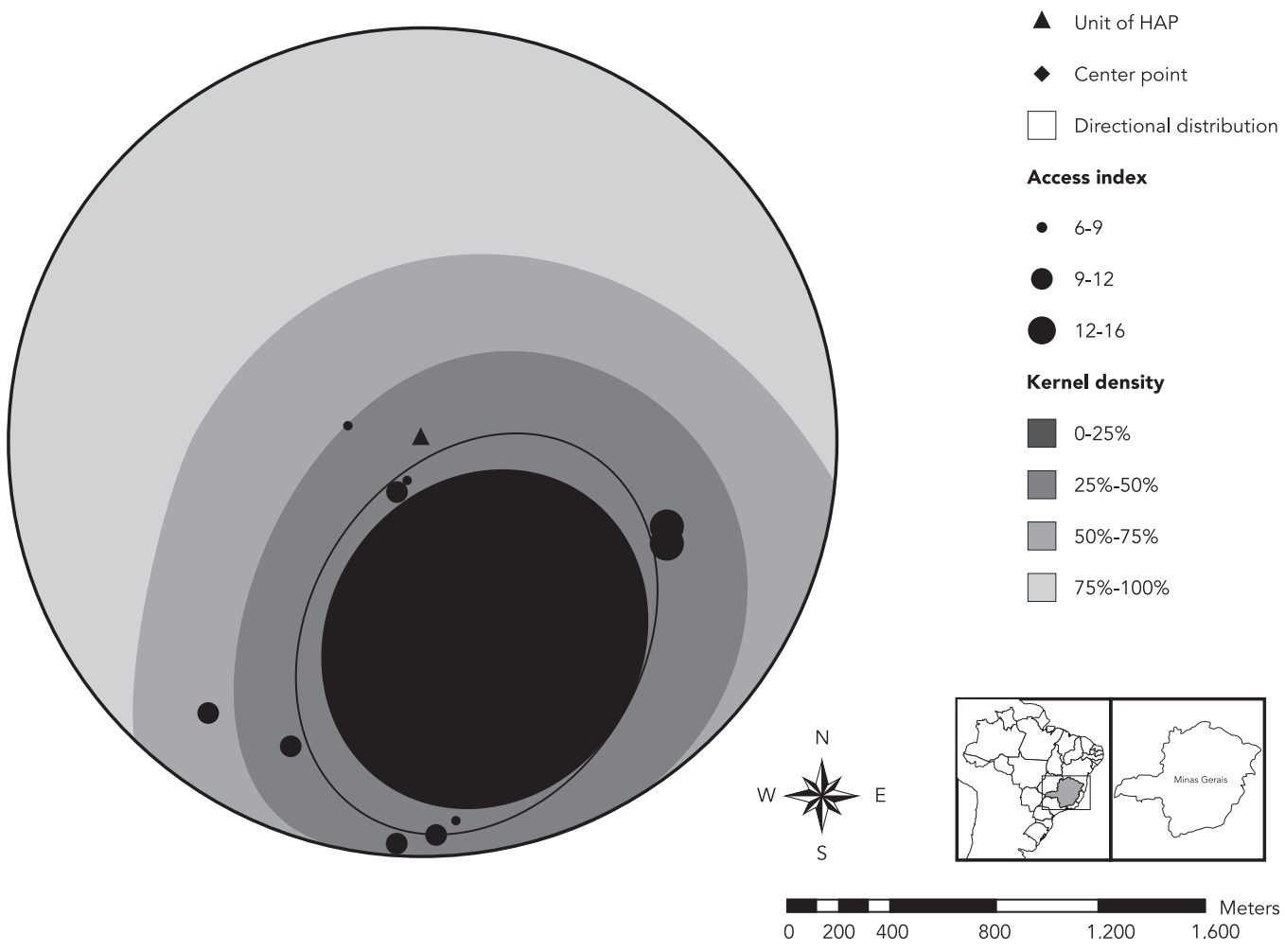

Despite the predominance of green grocery stores and open-air markets in the HAP territory, there was also a high offer of ultra-processed products such as sweetened beverages (49\%) and corn chips and cream-filled chocolate cookies (39\%). The latter suggests easy access to these products, with higher exposure to unhealthy eating habits 21,24 , which can jeopardize the population's nutrition and health 25 . This exposure to unhealthy foods was corroborated by analysis of the index of access to food establishments: only $33 \%(n=111)$ of the establishments showed higher scores, represented by greater availability and variety of healthy products.

The results suggest that residents had limited access to commercial fruit and vegetable establishments with adequate availability and variety in the HAP territory. The HAP is a key component of primary health care and health promotion, but since the fitness units are located in areas that are poorly equipped to foster healthy food choices, it may yield unsatisfactory results in terms of food and nutritional education 12 . However, identification of areas with limited access to fruits and vegetables (as in the current study) can allow defining these areas as priority targets for public policies to supply healthy foods, integrating different types of equipment and policies, aimed at intersectoral collaboration for healthy eating environments and greater effectiveness of activities in food and nutritional education. In addition, mapping commercial fruit and vegetable establishments in the HAP territory, as done in this study, can orient food and nutritional education activities in the units, since the main barriers to acquiring fruits and vegetables are access and quality. Such mapping can also foster community participation in building a healthy food environment.

Half of HAP units were located in areas bordering on other municipalities or in large uninhabited areas, which raises the discussion on health equity by analyzing geographic access. The location of these health promotion ser- 
Spatial distribution of commercial establishments selling fruits and vegetables in the territory of the Health Academy Program (HAP)-Centro-Sul 1. Belo Horizonte, Minas Gerais State, Brazil, 2013.

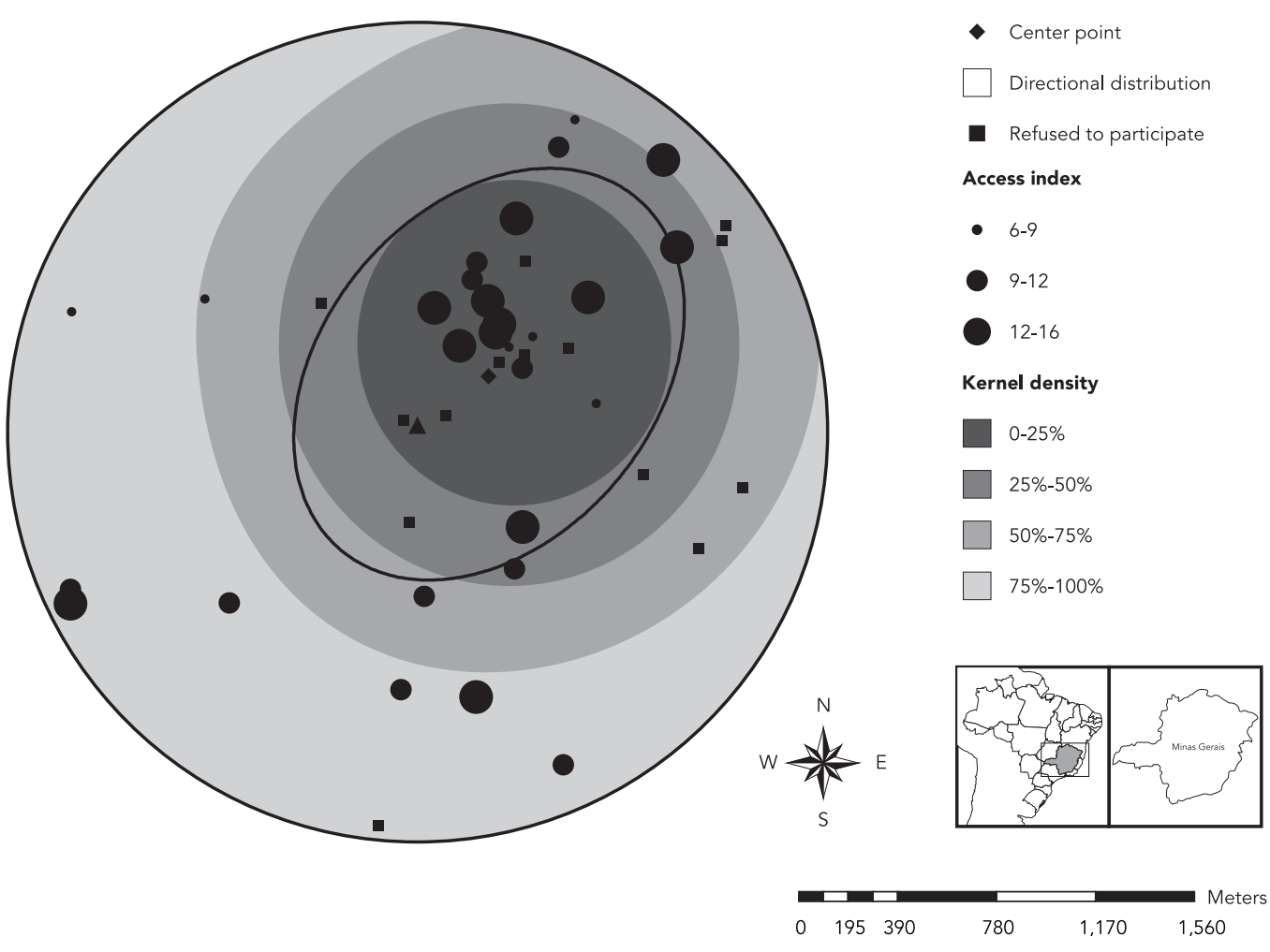

vices in areas with large uninhabited stretches may not be strategically effective for use by the population, since key determinants in the use of health services are distance to and availability and accessibility of health care ${ }^{26}$. There is no official rule on the places where the HAP units are supposed to be installed. Ruling n. 2,684/2013 27 by the Brazilian Ministry of Health only provides that these public fitness facilities should be installed in preexisting public spaces, preferably public squares, corners, and similar sites, providing free access to the population within the catchment areas of Basic Health Units (BHU), the reference services for primary care in Brazil. Although all the units of HAP studied here were located within catchment areas of BHU, a large share of the HAP units were located in large uninhabited areas. This highlights the importance of installing such facilities in well-inhabited areas where plenty of people circulate, in order to provide timely and easy access to other healthfriendly equipment in the same territory, such as establishments selling fruits and vegetables.

As for the food stores' spatial distribution, the clustering pattern in three HAP territories is explained by the fact that these areas displayed heavy circulation of people (as recommended in Ruling $n .2,684 / 201327$ ) and thus more commercial food establishments, plus a large municipal produce market in one territory. Municipal markets are characterized by diversified, broad, and affordable commerce, attracting other commercial establishments around them. These centers tend to favor competitiveness, where variety, convenience, quality, and price are important and distinctive attributes 28 . However, urbanization and population growth tend to fuel a demand for more municipal markets, and their expansion is seen as an alternative to promote access to fruits and vegetables 29 . 
In addition to the importance of healthy commercial food establishments and the expansion of new municipal markets, an equally important factor is the adequate registration of these establishments in a database. The study's results show that many of the registered establishments do not exist in fact, while other establishments are not registered in the municipal database. Such findings suggest the need for changes in data monitoring and updating, by encouraging regularization of commercial establishments with the Municipal Government, given the relevance of such data for formulating public policies and conducting robust scientific studies.

The study's limitations include the lack of identification of all the commercial establishments in the territories of some HAP units, due to their location near other municipalities that lack georeferenced data, preventing knowledge on the entire food environment in the territory of these units. Another limitation was the use of a buffer in determining the territory of the public fitness facilities and the acknowledgment of borders that may not correspond to these limits. Thus, the territory and access may be lesser or greater as a function of how these arbitrary limits are determined. However, the authors used a similar radius to that reported elsewhere in the literature $15,30,31$.

\section{Resumen}

Analizamos espacialmente la distribución y el acceso a tiendas de frutas y verduras en el territorio de una muestra representativa de lugares donde se realiza el Programa Academia de la Salud (PAS por sus siglas en portugués) de Belo Horizonte, Minas Gerais, Brasil. Evaluamos los establecimientos que aparecen en zonas acotadas con un radio de 1.600 metros, con respecto a 18 zonas procedentes de muestras al azar. La calidad de acceso a frutas y hortalizas se evaluó mediante el Índice de Acceso a los Establecimientos de Alimentación (IAA), integrado por variables de disponibilidad, variedad, anuncios de frutas y hortalizas, así como alimentos ultraprocesados. Se usó en este análisis el estimador de intensidad Kernel, el barrio más cercano y la función K
Ecological studies, like the current one, are essential, since they correlate the territory or context with access to healthy foods such as fruits and vegetables 21 . In addition, few studies have attempted to understand primary aspects of the food environment, such as quality, availability, and variety of foods, especially fruits and vegetables. Such knowledge can contribute to building a system for monitoring the food environment.

\section{Conclusion}

Within the territories of the HAP units, most of the commercial establishments were classified as green grocery stores and open-air markets, but there was limited access to establishments with adequate availability and variety of fruits and vegetables. The study suggests that public policies aiming to increase the offer of healthy foods should prioritize the territory in which these public fitness equipment units are located, especially in areas with limited access to these products. The ultimate goal is to promote intersectoral collaboration and healthier eating. de Ripley. De los 336 establecimientos encuestados, un $61,3 \%$ eran tiendas y mercados al aire libre, con una media de 11 IAA (5-16). Tan sólo en un 17\% del territorio analizado la mayoría de los establecimientos estaban situados en la zona más significativa, donde había un mejor acceso a alimentos sanos, e incluso tres áreas mostraron un patrón de aglomeración. Verificamos, asimismo, un acceso limitado a los establecimientos comerciales que ofrecen frutas y verduras en otras áreas del HAP, sobre todo en cuanto a la calidad.

Comercio; Alimentos; Análisis Espacial; Salud Urbana 


\section{Contributors}

B. V. L. Costa worked in the study design, data analysis and interpretation, and writing of the article. C. D. L. Oliveira participated in the data analysis and interpretation and revision of the manuscript. A. C. S. Lopes performed the fundraising for the study and participated in the study design, data analysis and interpretation, and revision of the manuscript.

\section{Acknowledgments}

The authors wish to thank the Division of Tax Registries of the Belo Horizonte Municipal Joint Taxation Secretariat and the Department of Primary Health Care of the Belo Horizonte Municipal Health Secretariat.

\section{References}

1. Kumanyika S. INFORMAS (International Network for Food and Obesity/non-communicable diseases Research, Monitoring and Action Support): summary and future directions. Obes Rev 2013; 14 Suppl 1:157-64.

2. Cohen SC, Barcelos MRB. Construção do "habitat-ação" saudável por meio de fundamentação teórico-metodológica do campo da semiologia do ambiente construído. Saúde Soc 2012; 21:747-59.

3. Campos ECS. Território e gestão de políticas públicas: uma reflexão sob a perspectiva do Sistema Único de Saúde - SUS. http://www.joinpp.ufma. br/jornadas/joinpp2011/cdvjornada/jornada_ei xo_2011/imHAPses_e_desafios_das_politicas_da seguridade_social/territorio_e_gestao_de_politi cas_publicas.pdf (accessed on 24/Apr/2014).

4. Secretaria de Vigilância em Saúde, Ministério da Saúde; Universidade de Brasília. Curso de extensão em promoção da saúde para gestores do SUS com enfoque no programa academia da saúde. Brasília: Ministério da Saúde/Universidade de Brasília; 2013.

5. Glanz K, Sallis JF, Saelens BE, Frank LD. Healthy nutrition environments: concepts and measures. Am J Health Promot 2005; 19:330-3.
6. Rose D, Richards R. Food store access and household fruit and vegetable use among participants in the US Food Stamp Program. Public Health Nutr 2004; 7:1081-8.

7. Zenk SN, Schulz AJ, Hollis-Neely T, Campbell RT, Holmes N, Watkins G, et al. Fruit and vegetable intake in African Americans: income and store characteristics. Am J Prev Med 2005; 29:1-9.

8. Ferreira VA, Silva AE, Rodrigues CAA, Nunes NLA, Vigato TC, Magalhães R. Desigualdade, pobreza e obesidade. Ciênc Saúde Coletiva 2010; 15:1423-32.

9. Duran ACFL, Diez-Roux AV, Latorre MRDO, Jaime PC. Neighborhood socioeconomic characteristics and differences in the availability of healthy food stores and restaurants in Sao Paulo, Brazil. Health Place 2013; 23:39-47.

10. Feng J, Glass TA, Curriero FC, Stewart WF, Schwartz BS. The built environment and obesity: a systematic review of the epidemiologic evidence. Health Place 2010; 16:175-90.

11. Costa BVL, Mendonça RD, Santos LC, Peixoto SV, Alves M, Lopes ACS. Academia da Cidade: um serviço de promoção da saúde na rede assistencial do Sistema Único de Saúde. Ciênc Saúde Coletiva 2013; 18:95-102. 
12. Franco M, Diez Roux AV, Glass TA, Caballero B, Brancati FL. Neighborhood characteristics and availability of healthy foods in Baltimore. Am J Prev Med 2008; 35:561-7.

13. Camara G, Carvalho MS. Análise espacial de eventos. http://mtc-m12.sid.inpe.br/col/sid.inpe.br/ sergio/2004/10.07.14.53/doc/cap2-eventos.pdf (accessed on 22/Oct/2013).

14. Diniz A. Estatística espacial. http://www.csr.ufmg. br/geoprocessamento/publicacoes/estespacial. pdf (accessed on 15/Jul/2014).

15. Block D, Kouba J. A comparison of the availability and affordability of a market basket in two communities in the Chicago area. Public Health Nutr 2006; 9:837-45.

16. Moore LV, Diez Roux AV. Associations of neighborhood characteristics with the location and type of food stores. Am J Public Health 2006; 96:325-31.

17. Bodor JN, Rose D, Farley TA, Swalm C, Scott SK. Neighborhood fruit and vegetable availability and consumption: the role of small food stores in an urban environment. Public Health Nutr 2007; 11:413-20.

18. Lee RE, Heinrich KM, Medina AV, Regan GR, Reese-Smith JY, JokuraY, et al. A picture of the healthful food environment in two diverse urban cities. Environ Health Insights 2010; 4:49-60.

19. Filomena S, Scanlin K, Morland KB. Brooklyn, New York foodscape 2007-2011: a five-year analysis of stability in food retail environments. Int J Behav Nutr Phys Act 2013; 10:46.

20. Healthy Eating Research. Bringing healthy foods home: examining inequalities in access to food stores. Research brief. Minneapolis: Healthy Eating Research; 2008.

21. Morland K, Wing S, Diez Roux A. The contextual effect of the local food environment on residents' diets: the atherosclerosis risk in communities study. Am J Public Health 2002; 92:1761-7.

22. Faller ALK, Fialho E. Disponibilidade de polifenóis em frutas e hortaliças consumidas no Brasil. Rev Saúde Pública 2009; 43:211-8.
23. Jaime PC, Duran AC, Sarti FM, Lock K. Investigating environmental determinants of diet, physical activity, and overweight among adults in Sao Paulo, Brazil. J Urban Health 2011; 88:567-81.

24. Giskes K, Lenthe FV, Avendano-Pabon M, Brug J. A systematic review of environmental factors and obesogenic dietary intakes among adults: are we getting closer to understanding obesogenic environments? Obes Rev 2010; 12:e95-e106.

25. Inagami S, Cohen DA, Finch BK, Asch SM. You are where you shop: grocery store locations, weight, and neighborhoods. Am J Prev Med 2006; 31:10-7.

26. Mendonza-Sassi R, Béria JU. Utilización de los servicios de salud: una revisión sistemática sobre los factores relacionados. Cad Saúde Pública 2001; 17:819-32.

27. Ministério da Saúde. Portaria no 2.684, de 8 de novembro de 2013. Diário Oficial da União 2013; 14 nov.

28. Aguiar DRD, Figueiredo AM. Poder de mercado no varejo alimentar: uma análise usando os preços do estado de São Paulo. Revista de Economia e Sociologia Rural 2011; 49:967-90.

29. Freire ALO. O desenvolvimento do comércio e a produção do espaço urbano. GeoTextos 2010; 6:11-32.

30. Moore LV, Diez Roux AV, Nettleton JA, Jacobs JR. Associations of the local food environment with diet quality: a comparison of assessments based on surveys and geographic information systems. Am J Epidemiol 2008; 167:917-24.

31. Charreire H, Casey R, Salze P, Simon C, Chaix B, Banos A, et al. Measuring the food environment using geographical information systems: a methodological review. Public Health Nutr 2011; 13:1773-85.

Submitted on $19 / \mathrm{Feb} / 2014$

Final version resubmitted on 04/Aug/2014

Approved on 03/Oct/2014 